\title{
Interest of Jan Kowalczyk in the Mining of Flint Raw Materials
}

\author{
Sławomir Sałaciński ${ }^{a}$, Barbara Sałacińska $^{b}$ and Wojciech Borkowski ${ }^{c}$
}

\begin{abstract}
Jan Kowalczyk exhibited great interest in the issues related to the prehistoric acquisition of flint raw materials and their working. He was involved in research and conservation issues at the turn of the I950s and I960s in the Neolithic and Early Bronze mines of banded flint in Krzemionki Opatowskie, exploited by communities of the Funnel Beaker, Globular Amphorae and Mierzanowice cultures. In 1967 and 1970 he was an inspirer and co-participant of Bogdan Balcer's research within the Świeciechów-type flint deposits in Świeciechów, near Annopol. The raw material was mined here using open-pit methods, constituting the oldest form of mining. The mines were at the same time centres of mass flint production. Świeciechów flint was used from the Paleolithic period throughout the Neolithic to the Bronze Age.
\end{abstract}

KEY-WORDS: Neolithic, Funnel Beaker culture, Globular Amphora culture, Early Bronze Age, Mierzanowice culture, prehistoric mining, banded flint, Krzemionki Opatowskie, Świeciechów flint, Świeciechów, flint workshops.

Jan Kowalczyk worked in the State Archaeological Museum in Warsaw (PMA) in 1954-1972. He was employed as the Head of the Neolithic Department, and in the last two years - as Deputy Director for Research. He created an outstanding team with such researchers of the Neolithic as: Elżbieta Kempisty, Bogdan Balcer, Anna Uzarowicz -Chmielewska and Jerzy Głosik. He was the initiator of various scientific activities and excavation campaigns on the Sandomierz Upland, Lublin Upland, in the Masurian Lake District, Mazovia and Podlasie. The publications of the members of this team have not lost their relevance until today and are among the leading works in the literature devoted to the Neolithic in Poland. The approach of J. Kowalczyk to his employees was best expressed by B. Balcer - I always say that docent Jan Kowalczyk has guided me "from student to docent". In the profession I owe him as much as to my parents in life (Balcer 2015: 134).

a State Archaeological Museum in Warsaw, 52, Długa st., 00-24I Warsaw, Poland, e-mail: neolit@pma.pl ORCID: 0000-0002-0767-8979

b State Archaeological Museum in Warsaw, 52, Długa st., 00-24I Warsaw, Poland, e-mail: neolit@pma.pl ORCID: 0000-00oI-6I26-397X

State Archaeological Museum in Warsaw, 52, Długa st., 00-24I Warsaw, Poland, e-mail: wborkowski@ pma.pl ORCID: 0000-0002-8637-8666 
I86 Stawomir Sataciński, Barbara Satacińska, Wojciech Borkowski

Jan Kowalczyk is the author of one of the most important studies concerning the beginnings of the Neolithic period in Poland (1969), which initiated a dynamic discussion among Stone Age researchers. These resulted in articles by E. Kempisty and Jan Gurba (197I), Janusz Krzysztof Kozłowski (197I) and B. Balcer (1971b). B. Balcer emphasized that J. Kowalczyk, as one of the few researchers in the mid-twentieth century, recognized the research on Neolithic flint working as an important item in the synthetic work concerning the Later Stone Age (Balcer 197Ib: 5I).

J. Kowalczyk exhibited great interest in the issues related to obtaining flint raw materials in the Neolithic in the territory of Poland. He was involved in scientific problems, conservation and public presentation of matters related to the prehistoric flint mines in Krzemionki Opatowskie, Ostrowiec Świętokrzyski district (Fig. I), exploited by the Neolithic communities of the Funnel Beaker culture (FBC), Globular Amphora culture (GAC) and - marginally - Early Bronze Age Mierzanowice culture (Borkowski et al. 1989: 20I-207). During the research conducted in the complex of mines in Krzemionki Opatowskie, at the end of the 1950s, he collaborated with Tadeusz Żurowski from the Ministry of Culture and Art, as well as with J. Gurba from the Maria Curie-Skłodowska University in Lublin, Andrzej Kempisty from the University of Warsaw and Zygmunt Krzak from the then Institute of the History of Material Culture (currently the Institute of Archaeology and Ethnology) of the Polish Academy of Sciences - IAE PAN (Lech 1999: 7I). B. Balcer has repeatedly mentioned that he owes his work on Neolithic flint working to J. Kowalczyk, who also contributed to his participation in the research of T. Zurowski in Krzemionki Opatowskie in 196I (Balcer 20I4: 109). During this period, archaeological work was concentrated in an area of workings of the pillar-chamber mines, No. 2 and 3, feature No. I was back filled by T. Żurowski due to strong destruction (Sałaciński 1997: 20). This had been initially cleared of debris by Stefan Krukowski in the I920s and I930s, though only brief interim reports ever appeared (Krukowski 1939: II8-I2O). In addition, the team of T. Żurowski explored the shaft and workings of the chamber mine No. 4 (Żurowski 196r: 28).

The research work in Krzemionki Opatowskie in the 1950s, in which J. Kowalczyk participated, was summarized by T. Żurowski in an article which presented the conservation aspects, a description of mining pits and the discovered artefacts; an attempt was made to pre-characterize the mines and to undertake a taxonomic analysis (Żurowski 1960).

J. Kowalczyk was a co-author (along with B. Balcer, J. Głosik and Zdzisław Rajewski) of the scenario of an exhibition devoted to prehistoric mining, realized in 1968 (Rajewski 197I: 2I). Issues related to Krzemionki Opatowskie, mining and flint production found their place in the popular science book by J. Kowalczyk, Zmierzch epoki kamienia [The Twilight of the Stone Age] (1971). He described in it an exploitation field with perfectly preserved post-mining surface relief in the form of funnel-shaped openings of underground shafts and heaps of limestone debris surrounding them, putative 


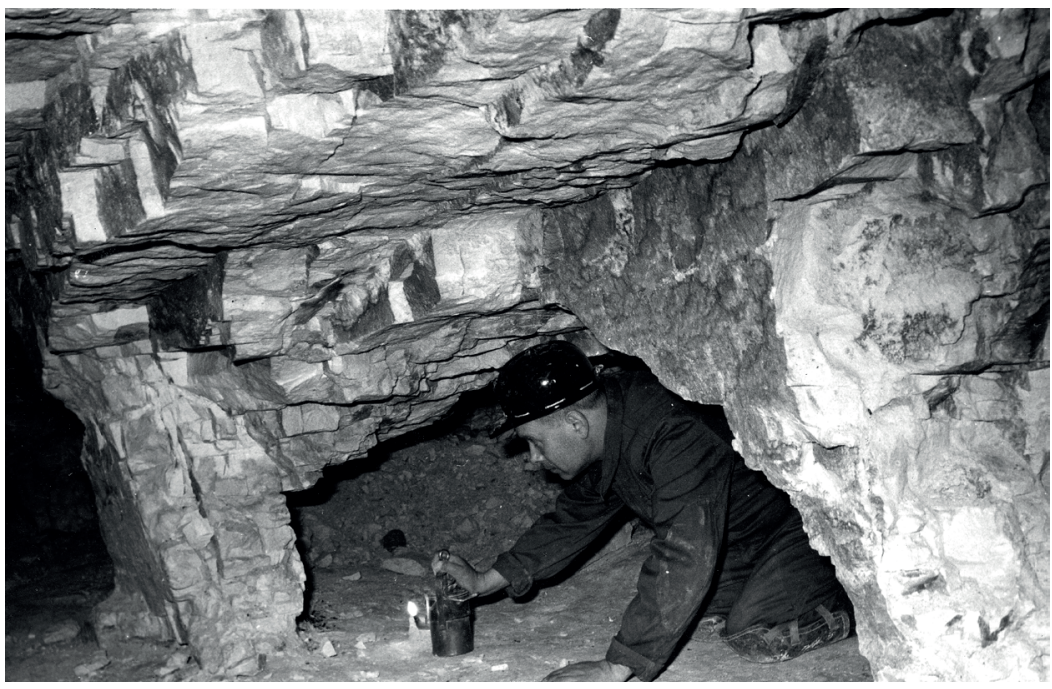

Fig. I. Jan Kowalczyk in the underground in the mines in Krzemionki Opatowskie, Ostrowiec Świętokrzyski district. Photo: D. Kostkowski, PMA Archive.

mining and flint working techniques, as well as modern destruction of mines (Kowalczyk 197I: 85-9I).

J. Kowalczyk was also a co-author of one of the concepts for the management of the Krzemionki reserve. The assumptions of this study included preliminary plans for the creation of a museum centre in Krzemionki with exhibitions devoted to the prehistoric flint mining, storage rooms for the collections and a research station with workrooms and housing facilities. It was to be located beyond the outskirt of the mines, in the place of buildings of the former Krzemionki village (Balcer 20I5: I44). It was also planned to conduct archaeological research on the exploitation field.

In accordance with the above-mentioned project, in the years 1969-1970 J. Kowalczyk directed, in cooperation with B. Balcer and Z. Krzak, archaeological excavations in the area of mine No. 5 in Krzemionki Opatowskie (Fig. 2). One of the main research objectives was to determine the state of preservation of the mines in this area of the exploitation field. These works were also aimed to establish an appropriate methodology of exploration, allowing to study the stratigraphy as well as the scatter pattern of waste dumps, shaft fillings and flint workshops situated within the area of the mines (Balcer 1996: 172). The study covered the area of $28 \times 15 \mathrm{~m}$. After cleaning the surface of the vegetation, a backfilled shaft in a funnel form with surrounding waste heaps was uncovered (Fig. 3, 4). The trench marked out in 1969 had dimensions $5 \times 6 \mathrm{~m}$, in 1970 


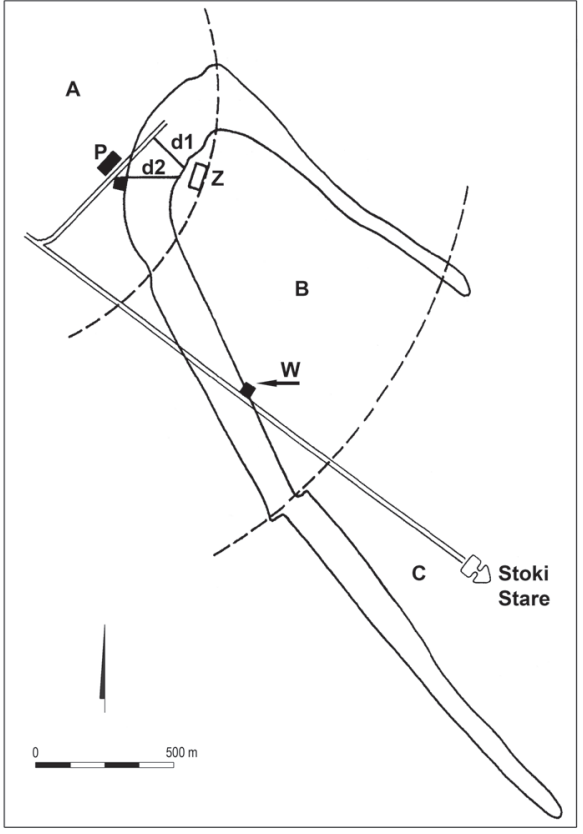

Fig. 2. Krzemionki Opatowskie, Ostrowiec Swiętokrzyski district. Location of the research area of the mine No. 5. A, B, C-segments of exploitation field; $\mathrm{Z}$ - the farmhouse of J. Pachniak and the later base of the expedition; $\mathrm{P}$ - pavilions from 1969; W - location of the trench from 1969-1970; di - the approach road to J. Pachniak's farm; $\mathrm{d} 2$ - the approach road to the expedition base. Location of the excavation. According to B. Balcer 1996, Fig. I, revised; Graphic design: B. Sałacińska.

it was expanded by $\mathrm{I} \mathrm{m}$ and reached the dimensions of $6 \times 6 \mathrm{~m}$. It was divided into four quadrants (A-D).

During the exploration, the outlines of three flint workshops, defined as clusters (Fig. 3), were partially discerned. In two of them axe roughouts and blanks were shaped, and they were finished in the other. The workshops were located north, southeast and south-west of the shaft, at a depth of $80-100 \mathrm{~cm}$. In the first cluster, IIOO flint artefacts were discovered, in the second - over 500, in the third - 300 (Balcer 1996: 179, Fig. 6, 7). In total, more than 3000 flint artefacts were found, mainly flakes, industrial chunks, unworked fragments of flint, and pre-cores. A few core forms, splintered pieces and retouched tools were identified as well as three tools made from antlers: two from deer antlers, one from elk (Fig. 5). Most of the artefacts (75\%) came from the quarter A (Fig. 6), 20\% - from D, 5\% - from B (Balcer 1996: 179).

Under the waste heap, at a depth of about $90 \mathrm{~cm}$, fragments of the outline of a mine shaft were uncovered (Fig. 3), which probably had dimensions of $360 \times 420 \mathrm{~cm}$ (Balcer 1996: 182). The exploration was completed at a depth of approximately $100 \mathrm{~cm}$.

B. Balcer attributed the acquired material to the Lesser Poland industry of the FBC or to the gierecki industry of the GAC. A detailed description of the research results, including stratigraphic data, scatter patterns, analysis of artefacts, the taxonomic determinations of the finds, were included in the study cited above (Balcer 1996). At the 


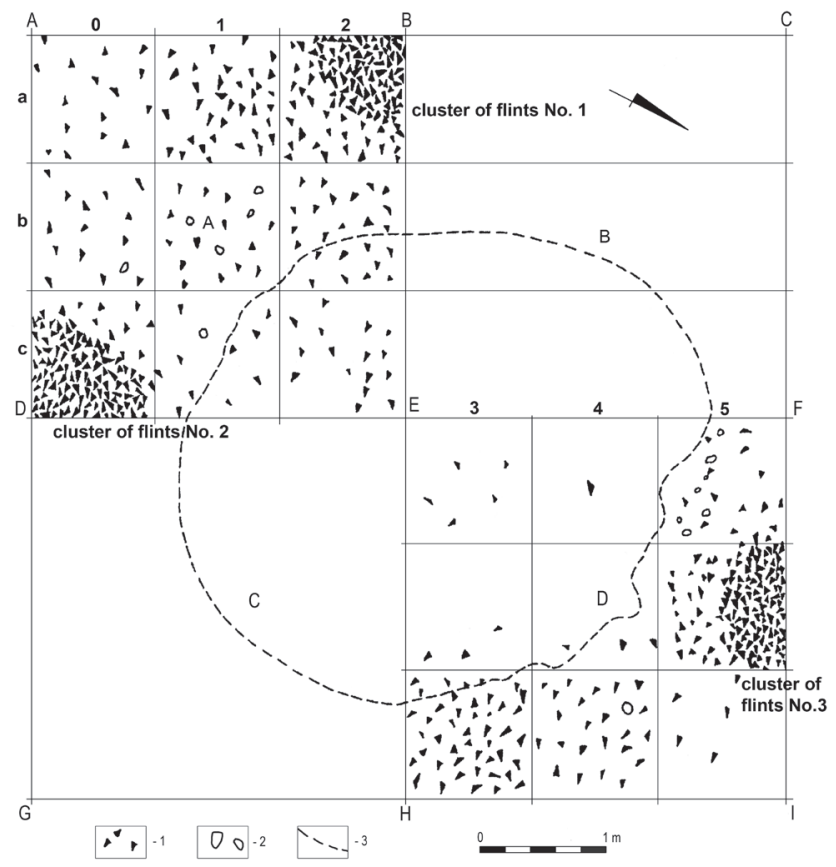

Fig. 3. Krzemionki Opatowskie, Ostrowiec Świętokrzyski district. Outline of the mine No. 5 and location of clusters of flint at a depth of 80-100 cm. I - flints; 2 - stones; 3 - limit of the shaft outline. According to B. Balcer 1996, Fig. 7, revised. Graphic design: B. Sałacińska.

time of writing of this article, the fates of the artefacts obtained from the 1969-1970 season were not known. Searches executed in the PMA and IAE PAN collections and in the available assemblages from the Historical and Archaeological Museum in Ostrowiec Świętokrzyski and the Archaeological Reserve in Krzemionki Opatowskie unfortunately did not give positive results.

J. Kowalczyk was also an inspirer of B. Balcer's research in the area of the Świeciechów-type flint mines in Świeciechów, Kraśnik district (Fig. 7), which were discovered in 1923 by Jan Samsonowicz (Samsonowicz 1924). In 1963, Z. Krzak (1965) recognized the surface evidence of the exploitation area of the Świeciechów raw material. Excavation work was preceded by multiple surveys of the area of the Turonian flint deposits near Annopol, Kraśnik district carried out by B. Balcer and J. Kowalczyk. The research was conducted on behalf of PMA in the years 1963-1967 as part of the Neolithic settlement recognition program on the edge of the Sandomierz Upland (Balcer 1971a: 7I-72). Their main purpose was to determine the stratigraphy of the 
I9o | Stawomir Satacinski, Barbara Satacińska, Wojciech Borkowski

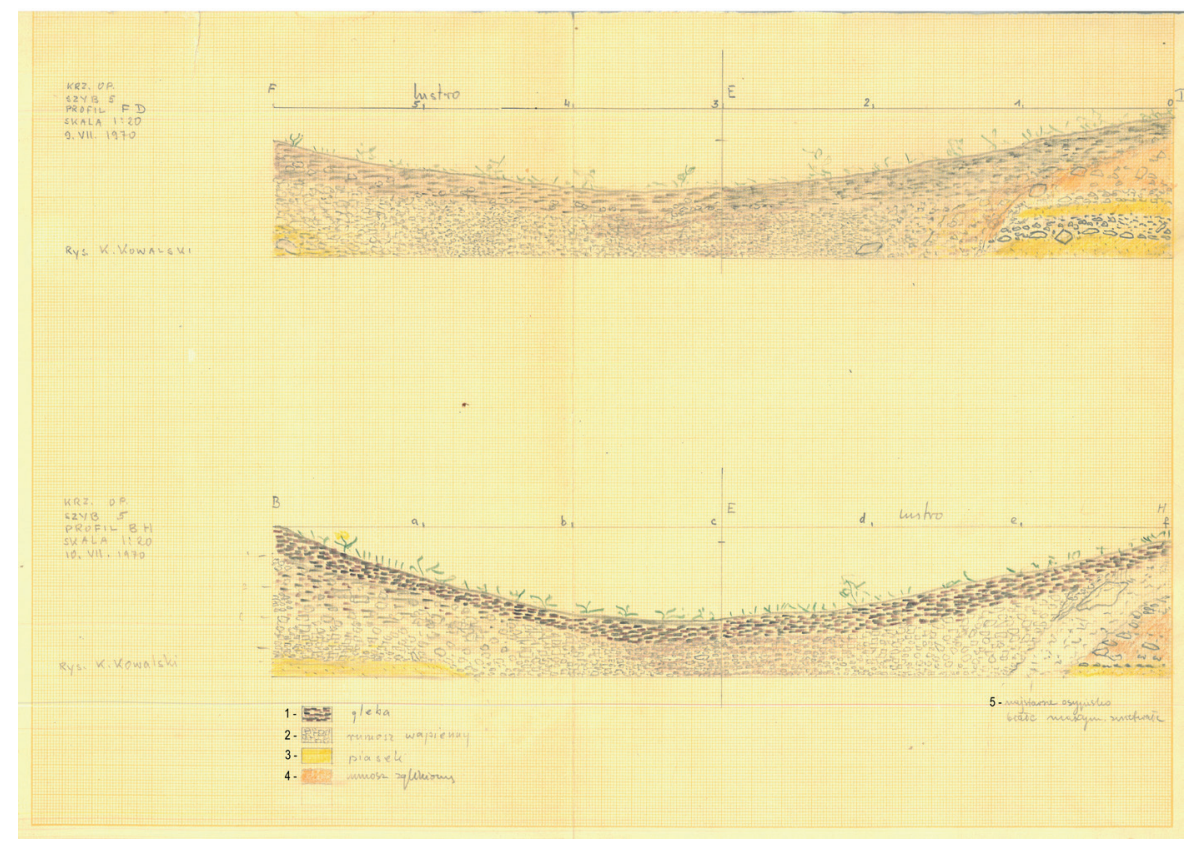

Fig. 4. Krzemionki Opatowskie, Ostrowiec Świętokrzyski district. Profiles of the trench within mine No. 5 with visible depression of the shaft, 1970. I - humus; 2 - limestone rubble; 3 - sand; 4 - clay with limestone rubble; 5 - the oldest talus deposit; Z. I - depression No. I. Drawing: K. Kowalski, PMA Archive.

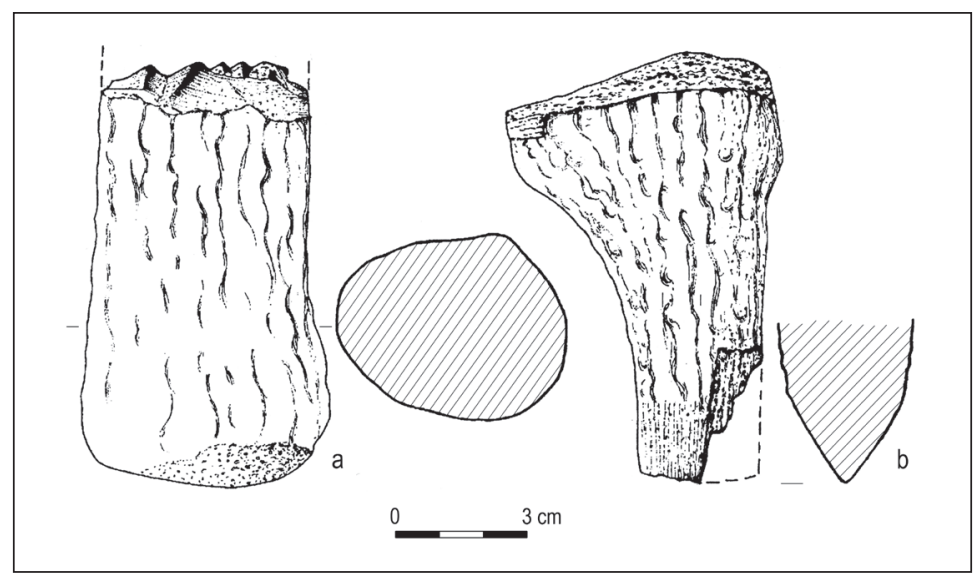

Fig. 5. Krzemionki Opatowskie, Ostrowiec Świętokrzyski district. Fragments of mining tools of antler discovered during the research of mine No. 5. A - a toothed tool from a mallet; b - wedge. According to B. Balcer 1996, Fig. 9, revised. Graphic design: B. Sałacińska. 


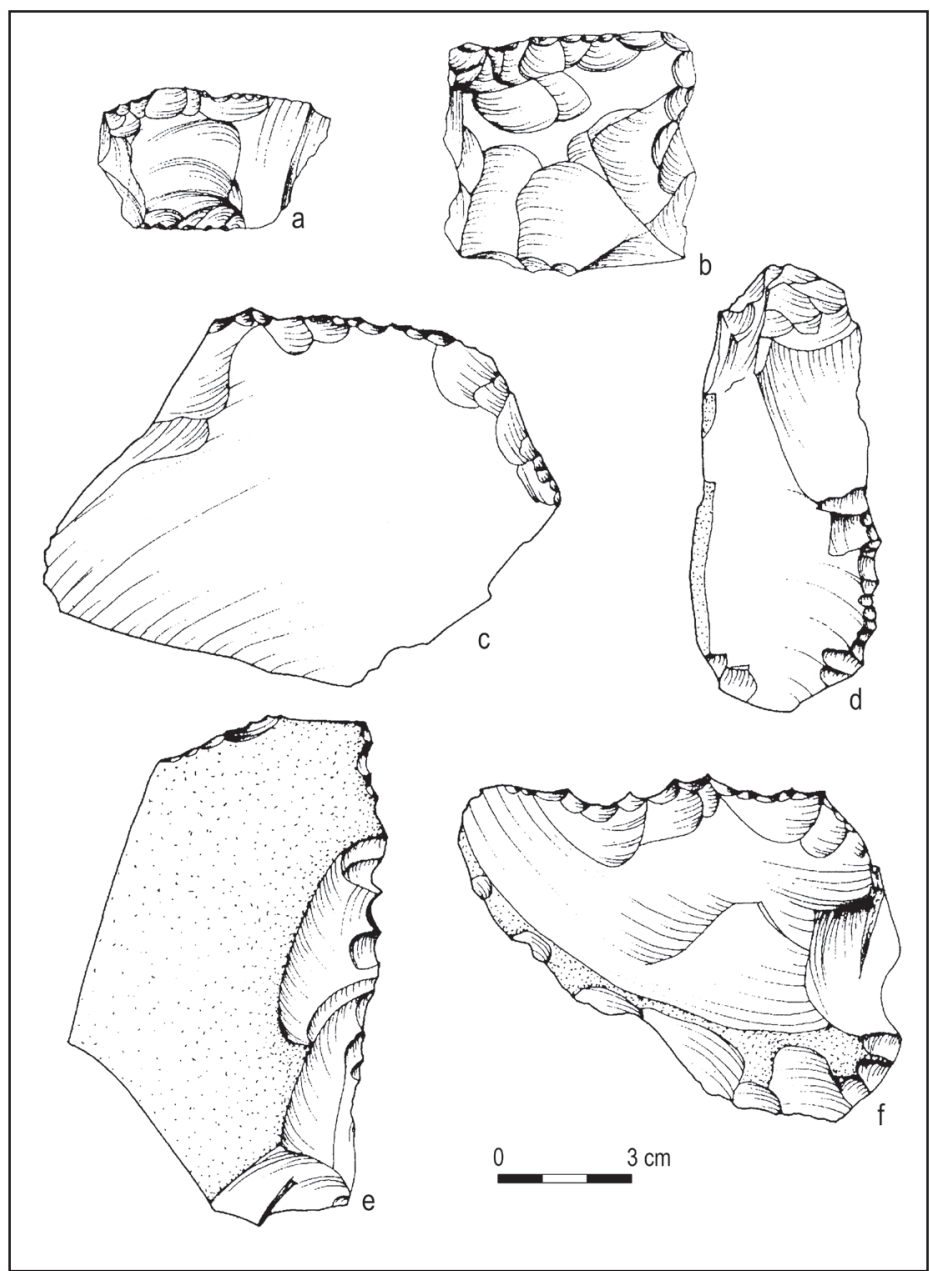

Fig. 6. Krzemionki Opatowskie, Ostrowiec Świętokrzyski district. Finds of banded flint from research in mine No. 5 a, b-splintered pieces; $\mathrm{c}$ - a sidescraper; $\mathrm{d}$ - retouched blade-flake; $\mathrm{e}, \mathrm{f}$ - toothed tools. According to B. Balcer 1996, Fig. 8, revised. Graphic design: B. Sałacińska.

grey, white-dotted Turonian flints raw materials originating from the right-bank deposits on the Rachów anticline (Balcer 1975: 46, I49), to reconstruct their exploitation methods and determining - based on production residues - the relationships of the mines with local settlements (mainly with the settlement in Zawichost, site "Pieczyska-Zbrza Wielka", Sandomierz district and with the settlement in Ćmielów, site "Gawroniec", Ostrowiec district). 
I92 Stawomir Sataciński, Barbara Satacińska, Wojciech Borkowski

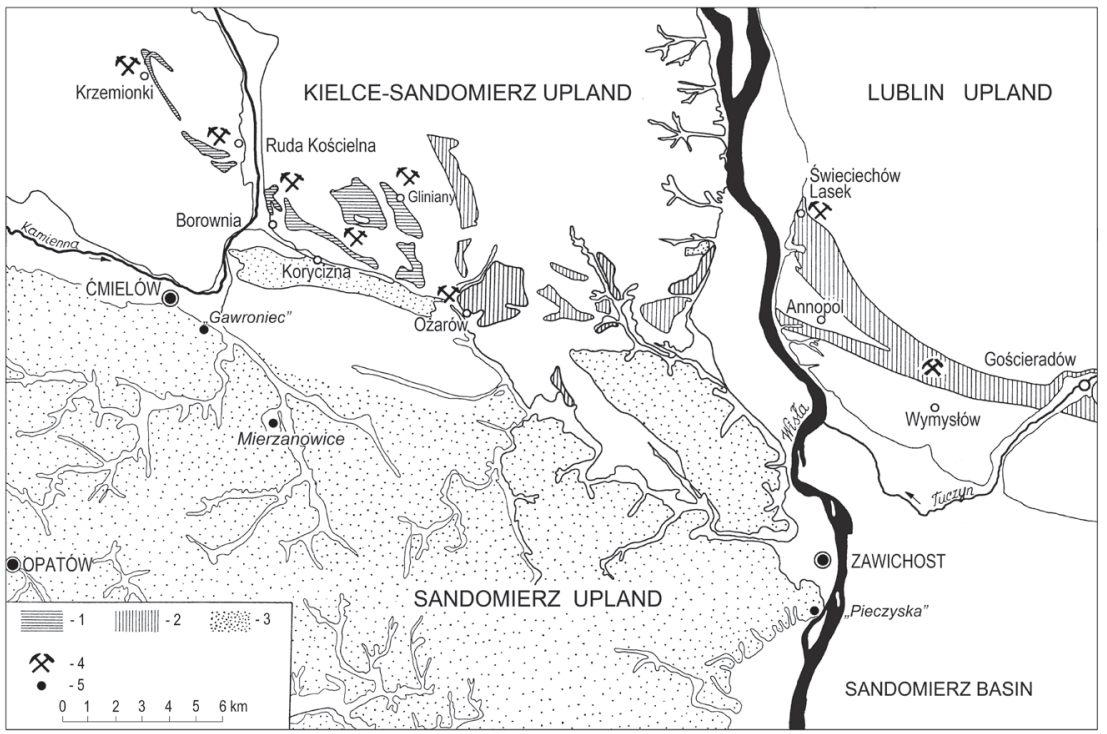

Fig. 7. Location of the Świeciechów flint mines within the eastern Łysogóry region of prehistoric mining. I - Astart; 2 - Turon; 3 - loess; 4 - flint mines; 5-main settlement points. According to B. Balcer 197ıb, Fig. I, revised. Graphic design: B. Sałacińska.

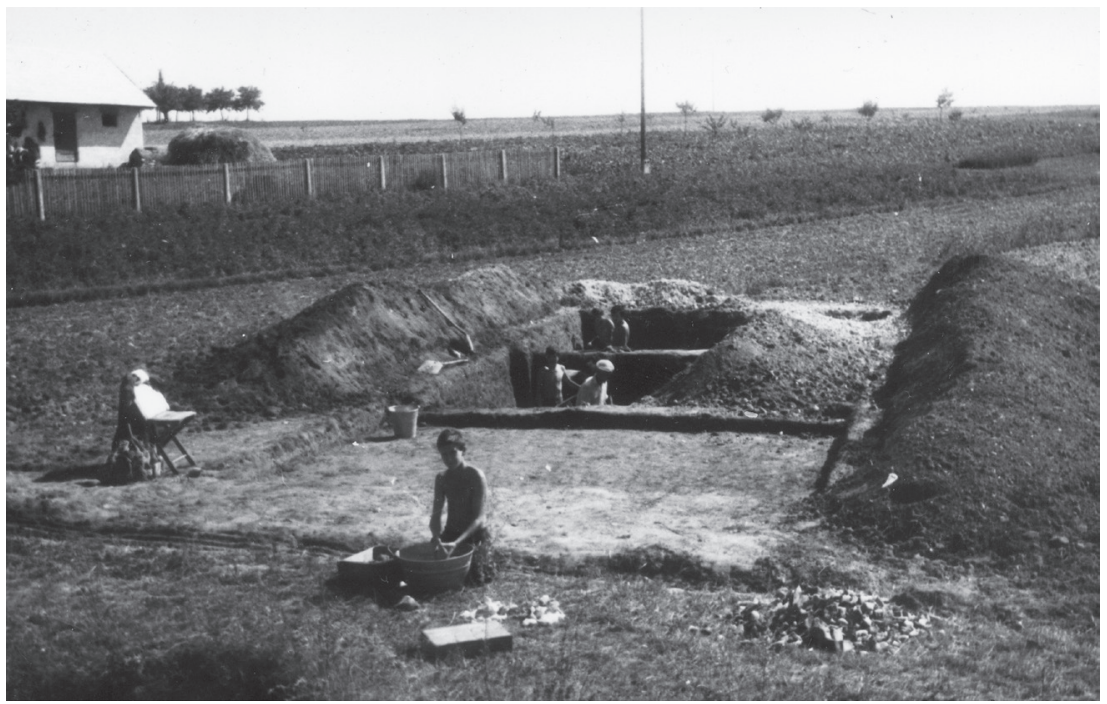

Fig. 8. Świeciechów, Kraśnik district. Excavation in 1967. Photo: PMA archive. 


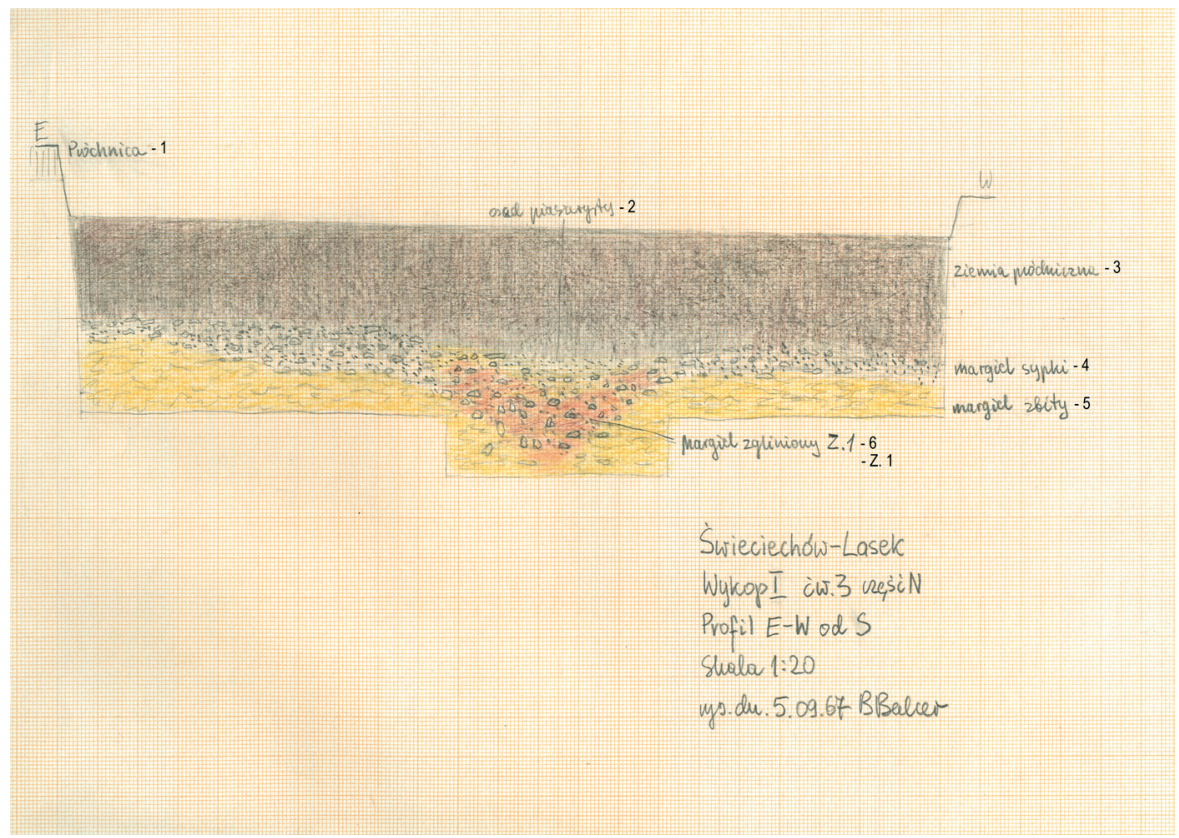

Fig. 9. Świeciechów, Kraśnik district. Profile of trench I, 1967. I, 3- humus; 2 - sand; 4-limestone dust; 5 - limestone rubble; 6 - clay with limestone rubble. Drawing: B. Balcer, PMA Archives.

J. Kowalczyk was also the author of a program of an exploratory research and test excavations in the area reaching from Sandomierz to Świeciechów, measuring approximately $15 \times 35 \mathrm{~km}$, with a surface of $525 \mathrm{~km}^{2}$ (Kowalczyk 1962a: 302). Its initial implementation started in 1962 . The research team was composed of J. Kowalczyk, B. Balcer and E. Kempisty. The area penetrated have been the so-called "Góry Pieprzowe" [Pepper Mountains] near Sandomierz, the edge of the Opatówka valley on the section from Kichary to Dwikozy, the edge of the Sandomierz Upland between Dwikozy and Zawichost and the flint mines in Świeciechów (Kowalczyk 1962a: 303-304).

In 1967 and 1970 B. Balcer, assisted by J. Kowalczyk, carried out test excavations at a mine site in Świeciechów (Fig. 8, 9). The results of the work allowed to assess that the flint in the area of Świeciechów was acquired using the open-pit method, which is the oldest form of mining. In the test trenches in the western part of the site, slight traces of depressions with rounded bottoms were found. They cut the weathered layer up to the level of $55-85 \mathrm{~cm}$, originally being probably deeper. The depressions were $80-I 20 \mathrm{~cm}$ wide, and their length documented in the trenches was up to I60 cm (Balcer 2002: 24). B. Balcer considered them to be traces of the lower parts of opencast exploitation 
I94 Stawomir Sataciński, Barbara Satacińska, Wojciech Borkowski

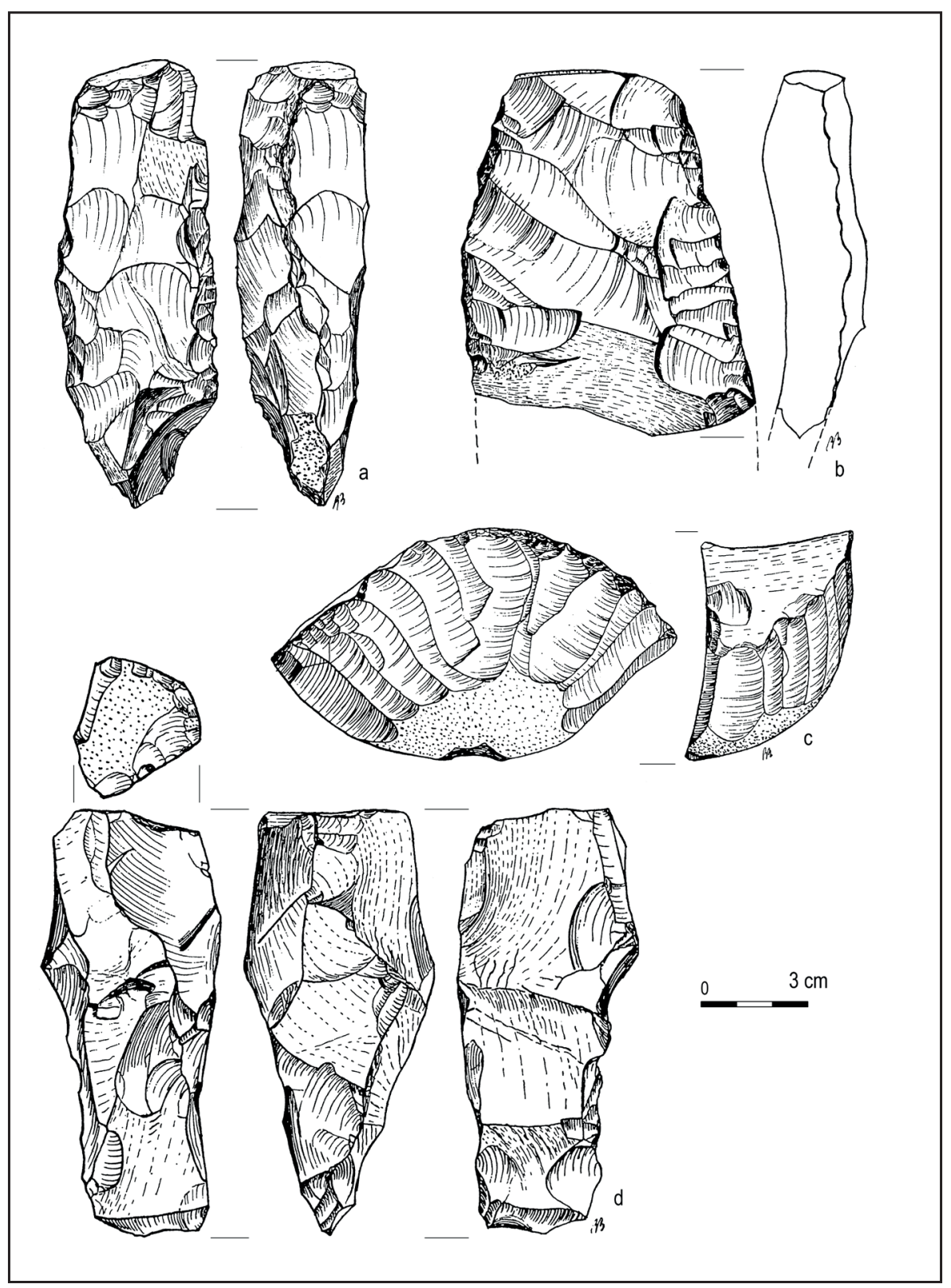

Fig. 1o. Świeciechów, Kraśnik district. Artefacts of Świeciechów flint. a, d-picks, b - fragment of a tetrahedral axe blank; c - a blade core. Drawing: B. Balcer. According to B. Balcer 1971, Table I, revised. Graphic design: B. Sałacińska. 
excavations in the form of oval pits or longitudinal trenches, next to which the workshops of preliminary flint processing were located (I971a: 91-92; 1975: 162; 2002: 24). The mines were at the same time centres of mass flint production, as evidenced by the accumulation of waste from various production phases, mainly from the initial stages of shaping products (Balcer 1975: I77). In the inventory recovered from Świeciechów, unfortunately, as many as 90\% were unworked fragments of flint, and only Io\% - flints with traces of working, including 6\% - core forms: pre-cores, flake and blade cores, tool preforms (Balcer I97Ia: 95-I08, Table I-XIII). The Świeciechów raw material was used from the Paleolithic to the Bronze Age (Balcer I97Ia: I22-I29; 1975: 158). In the flint material from this site, B. Balcer distinguished products belonging to the Late Paleolithic, Mesolithic, Neolithic Danubian cultures, FBC, GAC (Fig. IO, II) and the Early Bronze Mierzanowice culture (Balcer 2002: 24). To the artefacts of the Lesser Poland industry of the FBC, he included the roughouts and blanks of tetrahedral axes and production residues of exquisite macrolithic blades and cores. Neolithic miners were thought to have lived in the settlement in Zawichost, at the site "Pieczyska-Zbrza Wielka", and reaching the source of the raw material and its transport could be enabled by the Vistula. The industrial character of the settlement was described by B. Balcer on the basis of the mass processing of the Świeciechów flint in its area (Balcer I968: 355).

J. Kowalczyk was undoubtedly a researcher who was also a synthetist. Prehistoric mining and flint working were only two of his many interests in researching the Neolithic. As one of the basic issues, he recognized the analysis of complexes of evidence referred to as archaeological cultures, groups or cycles (Kowalczyk 1969: 6). In his studies, he addressed the fundamental aspects of the Neolithic, for example, its definition, genesis, chronology. He emphasized the significance of comparative studies, developmental regularities, and ethnic problems (Kowalczyk I962 b: 272). Some of his views in this regard met with criticism, but many remain still valid.

Translated by Andrzej Leligdowicz

\section{REFERENCES}

Balcer, B. 1968. Stanowisko Pieczyska (Zbrza Wielka) w Zawichoście-Podgórzu, pow. Sandomierz w świetle pierwszych wykopalisk. Wiadomości Archeologiczne 32(3-4)/1966-1967: 290-375.

Balcer, B. I97ra. Kopalnie krzemienia w Świeciechowie-Lasku, pow. Kraśnik w świetle badań 1967 r. Wiadomości Archeologiczne 36(I): 7I-132.

Balcer, B. 197Ib. O stanie i potrzebach w zakresie badań krzemieniarstwa neolitu i wczesnej epoki brązu. Wiadomości Archeologiczne 36(I): 5I-70.

Balcer, B. 1975. Krzemień świeciechowski w kulturze pucharów lejkowatych. Eksploatacja, obróbka i rozprzestrzenienie. Wrocław-Warszawa-Kraków-Gdańsk. 
I96 $\mid$ Stawomir Sataciński, Barbara Satacińska, Wojciech Borkowski

Balcer, B. 1996. Cel i wyniki badań w Krzemionkach w latach 1969-1970. In W. Brzeziński, W. Borkowski and W. Migal (eds), Z badań nad wykorzystaniem krzemienia pasiastego, 167-193. Warszawa. Studia nad gospodarką surowcami krzemiennymi w pradziejach 3.

Balcer, B. 2002. Ćmielów - Krzemionki - Świeciechów. Związki osady neolitycznej z kopalniami krzemienia. Warszawa.

Balcer, B. 20I4. Krzemionki w moich wspomnieniach z lat 1954-I972. In D. Piotrowska, W. Piotrowski, K. Kaptur and A. Jedynak (eds), Górnictwo z epoki kamienia: Krzemionki - Polska - Europa, I05-I2I. Ostrowiec Świętokrzyski. Silex et Ferrum I.

Balcer, B. 2015. Sześćdziesiąt lat z archeologia w życiu cyklisty. Łódź.

Borkowski, W., Migal, W., Sałaciński, S. and Zalewski, M. 1989. Urgeschichtlicher Feuersteinbergbau im Gebiet von Krzemionki. Ein Bericht zum Stand der Forschung. Praehistorische Zeitschrift 64(2): I64-207.

Kempisty, E. and Gurba, J. 1971. Z zagadnień początków neolitu polskiego. Wiadomości Archeologiczne 36(I): $38-43$.

Kowalczyk, J. 1962a. "Sondaż terenowy” w badaniach archeologicznych. Wiadomości Archeologiczne 28(4): 30I-307.

Kowalczyk, J. 1962b. Uwagi o problematyce i postulatach badawczych neolitu polskiego. Wiadomości Archeologiczne 27(3): 271-282.

Kowalczyk, J. 1969. Początki neolitu na ziemiach polskich. Wiadomości Archeologiczne 34(I): 3-69.

Kowalczyk, J. 1971. Zmierzch epoki kamienia. Wrocław-Warszawa-Kraków-Gdańsk.

Kozłowski, J. K. 197I. W sprawie początków neolitu na ziemiach polskich. Wiadomości Archeologiczne 36(I): 44-50.

Krukowski, S. 1939. Krzemionki Opatowskie. Warszawa.

Krzak, Z. 1965. Tymczasowa charakterystyka kopalni krzemienia w Świeciechowie. Archeologia Polski I5: 2I7-233.

Lech, J. 1999. Tadeusz R. Żurowski jako konserwator, badacz i popularyzator zabytków prehistorycznego górnictwa krzemienia. In Z. Kobyliński and J. Wysocki (eds), Tadeusz Roman Żurowski i konserwatorstwo archeologiczne $w$ Polsce XX wieku, 63-80. Warszawa.

Rajewski, Z. 197I. Kopalnia krzemienia w Krzemionkach i jej problemy archeologiczno-muzealne. Wiadomości Archeologiczne 36(I): 19-37.

Sałaciński, S. 1997. Krzemionki 1984-1992. Wiadomości Archeologiczne 53(2)/1993-1994: 19-29.

Samsonowicz, J. I924. Odkrycie pierwotnych złóż krzemienia "szarego biało nakrapianego". Wiadomości Archeologiczne 9(I-2): 99-IOI.

Żurowski, T. 1960. Górnictwo krzemienia nad rzeką Kamienną. Światowit 23: 249-279.

Żurowski, T. 1961. Nowe badania nad historią najstarszego górnictwa w Polsce. Kwartalnik Historii i Nauki 6(I): $25-44$. 